\title{
DOMESTIKASI IKAN BELIDA LANGKA, Chitalalopis (Bleeker, 1851): PEMBENIHAN SECARA TERKONTROL DI LUAR HABITAT ALAMI
}

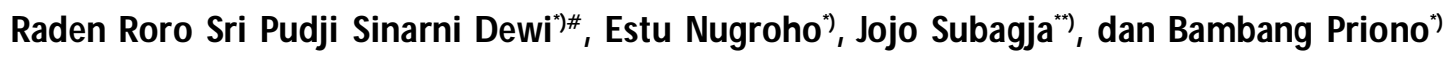 \\ *) Pusat Riset Perikanan \\ Gedung BRSDMKP II, Jalan Pasir Putih II, Ancol Timur, Jakarta Utara 14430 \\ * Balai Riset Perikanan Budidaya Air Tawar dan Penyuluhan Perikanan \\ Jl. Sempur No. 1, Bogor 16154
}

(Naskah diterima: 11 Februari 2019; Revisi final: 24 Juni 2019; Disetujui publikasi: 24 Juni 2019)

\begin{abstract}
ABSTRAK
Penelitian pemeliharaan ikan belida, (Chitala lopis Bleeker, 1851) secara ex-situ bertujuan untuk mendapatkan teknik pembenihan yang tepat di luar habitat alaminya. Serangkaian eksperimen dilakukan adalah: 1) pemeliharaan benih dalam akuarium dengan padat tebar berbeda (45, 90, dan 180 ekor/90 L); 2) pemeliharaan benih dalam akuarium dengan jenis pakan berbeda (pakan buatan dan cacing tubifex); 3 ) pemeliharaan benih dalam waring dengan padat tebar berbeda (10 dan $\left.20 \mathrm{ekor} / \mathrm{m}^{2}\right)$; dan 4) pembesaran dalam waring dengan jenis pakan berbeda (cacing tubifex; cacing tubifex + pakan buatan, dan pakan buatan). Pemeliharaan benih dalam akuarium menggunakan ukuran awal 3,4 $\mathrm{cm}$ selama 30 hari memperlihatkan kepadatan 45 ekor/90 L memberikan laju pertumbuhan bobot terbaik sebesar 3,1\%hari dengan sintasan $96,7 \pm 1,33 \%$ Pemeliharaan lanjutan selama dua bulan dalam akuarium dengan pemberian jenis pakan berbeda menghasilkan pertumbuhan bobot tertinggi pada benih yang diberi pakan cacing tubifex sebesar 2\% $\%$ hari dengan sintasan $29 \pm 3,42 \%$ Pemeliharaan benih ukuran $4,9 \mathrm{~cm}$ dalam waring yang diletakkan dalam kolam tanah menghasilkan pertumbuhan dan sintasan yang lebih tinggi pada padat tebar 10 ekor $/ \mathrm{m}^{2}$ dengan laju pertumbuhan bobot 2,6\% per hari dengan tingkat sintasan sebesar $77,3 \%$ Pembesaran benih dalam waring dengan ukuran tebar $8-9 \mathrm{~cm}$ selama dua bulan menghasilkan pertumbuhan bobot yang lebih tinggi pada benih yang diberi pakan cacing tubifex (1,3\%hari) dibandingkan dengan pakan buatan (0,6\%hari) dan campuran pakan buatan + cacing tubifex (1,0\%/hari).
\end{abstract}

KATA KUNCl: Chitala, belida; domestikasi; pembenihan

ABSTRACT: Domestication of endangered featherback fish, (Chitala lopis Bleeker, 1851): A controlled breeding out of natural habitat. By: Raden Roro Sri Pudji Sinarni Dewi, Estu Nugroho, Jojo Subagja, and Bambang Priono

Research on the domestication of featherback fish, (Chitala lopis Bleeker, 1851) outside of their natural habitat was carried out primarily to obtain its feasible breeding techniques. A series of experiments was carried out including 1 ) seed rearing in aquariums with different stocking densities $(45,90$, and $180 / 90 \mathrm{~L}) ; 2$ ) rearing of seeds in aquariums with different types of feed (artificial feed and tubifex); 3 ) seeds rearing in net cage with different stocking densities (10 and 20 fish/m2); and 4) grow-out in net cage with different types of feed (tubifex; tubifex + artificial feed, and artificial feed). The results showed that seeds with an initial size of $3.4 \mathrm{~cm}$ reared in an aquarium for 30 days with a density of 45 fish $/ 90 \mathrm{~L}$ produced the best weight growth of 3.1\% day with survival rate of $96.7 \pm 1.33 \%$ Two months of continued rearing carried out in an aquarium produced thehighest weight growth for seeds fed with tubifex of $2 \%$ day with survival rate of $29 \pm 3.42 \%$ Rearing of seeds sized $4.9 \mathrm{~cm}$ in net cage placed in earthen pond resulted in higher growth and survival than that of aquariums. The best density was $10 \mathrm{fish} / \mathrm{m} 2$ with weight growth rate of $2.6 \%$ per day and survival rate of $77.3 \%$ Seeds sized of $8-9 \mathrm{~cm}$ cultured in net cage for two months produced higher weight growth when feed with tubifex (1.3\% day) than that of feed with artificial feed $(0.6 \%$ day) and mixture artificial feed + tubifex (1.0\%day).

\section{KEYWORDS: Chitala; featheback fish; domestication; breeding}

\footnotetext{
\# Korespondensi: Pusat Riset Perikanan. Gedung BRSDMKP II,

Jalan Pasir Putih II, Ancol Timur, Jakarta Utara 14430, Indonesia

Tel.: + 622164700929

E-mail: sripudjisinarni@gmail.com
} 


\section{PENDAHULUAN}

Ikan belida termasuk ke dalam salah satu jenis ikan yang dilindungi berdasarkan Peraturan Menteri Lingkungan Hidup dan Kehutanan Nomor P.20/ MENLHK/SETJEN/KUM.1/6/2018 Tentang Jenis Tumbuhan dan Satwa yang dilindungi. Pertimbangan kebutuhan konsumen, nilai komersial, dan untuk menjaga keanekaragaman hayati menuntut adanya upaya pelestarian jenis satwa beserta ekosistemnya baik di dalam maupun di luar habitatnya. Oleh karena itu, studi biologi dan domestikasi ikan belida sangat diperlukan.

Pada sebagian besar spesies yang didomestikasi akan menunjukkan plastisitas/kelenturan tingkah laku yang dapat membuatnya mampu beradaptasi dalam wadah budidaya dan pada lingkungan yang berbeda dengan habitat alaminya (Driscoll et al., 2009). Beberapa penelitian yang telah dilakukan terkait ikan belida antara lain reproduksi (Kohinoor et al., 2012; Srivastava et al., 2010; Hossain et al., 2006; Kristanto et al., 2008; Gustomi et al., 2016), keragaman genetik (Sodsuk \& Sodsuk, 2000; Wibowo \& Marson, 2012; Sarkar et al., 2009), dan embriogenesis (Srivastava et al., 2012).

Pada program domestikasi ikan belida diperlukan pengembangan teknik pemeliharaan induk, pemijahan, pemeliharaan benih, dan pembesaran. Pada saat ini, informasi teknik pemeliharaan ikan belida masih sangat terbatas. Keberhasilan dalam pemijahan dan pembesaran ikan belida dalam wadah budidaya akan sangat membantu dalam pengembangbiakan ikan tersebut untuk memenuhi kebutuhan masyarakat. Penelitian ini bertujuan untuk menentukan teknologi pembenihan ikan belida dalam wadah budidaya untuk mendukung program domestikasi ikan belida.

\section{BAHAN DAN METODE}

Penelitian dilakukan pada bulan Maret-September 2018. Lokasi penelitian adalah unit pembenihan rakyat Sumatera Mandiri, Bukit Lama, Palembang, Sumatera Selatan.

Induk yang digunakan adalah ikan koleksi milik pembudidaya yang merupakan hasil tangkapan dari Sungai Musi dan dipelihara dalam kolam tanah. Pemilihan induk dilakukan dengan cara menyeleksi induk jantan dan betina berdasarkan ukuran. Ukuran induk jantan dan betina yang diseleksi adalah panjang total lebih dari $50 \mathrm{~cm}$ atau bobot lebih dari $1 \mathrm{~kg}$ (Gambar 1). Pemijahan dilakukan secara massal. Pada kolam pemijahan, ditempatkan papan kayu sebagai tempat penempelan telur. Selama pemeliharaan, induk diberi pakan anak ikan mas. Monitoring benih ikan yang dihasilkan dari pemijahan secara alami ini dilakukan setiap satu bulan sekali. Induk dan benih hasil pemijahan alami dipindahkan ke dalam akuarium (Gambar 1).

\section{Eskperimen-1: Pemeliharaan Benih dalam Akuarium dengan Padat Tebar Berbeda}

Pada eksperimen-1 dilakukan pengujian padat tebar yang berbeda. Benih ikan belida yang digunakan berukuran rata-rata $3,4 \mathrm{~cm}$. Benih dipelihara dalam akuarium berukuran $50 \mathrm{~cm} \times 85 \mathrm{~cm} \times 25 \mathrm{~cm}$ selama satu bulan. Perlakuan yang diujikan adalah padat tebar benih 45, 90, dan 180 ekor/90 L. Setiap perlakuan diulang sebanyak tiga kali. Selama pemeliharaan, benih diberi pakan cacing tubifex. Pengamatan pertumbuhan dilakukan setiap sepuluh hari. Sintasan dihitung pada akhir penelitian.

\section{Eksperimen-2: Pemeliharaan Benih dalam Akuarium dengan Jenis Pakan Berbeda}

Pada eksperimen-2 dilakukan pengujian pemberian pakan benih berupa pakan alami (cacing tubifex) dan pakan buatan (pakan pasta komersial berkadar protein $40 \%$. Setiap perlakuan diulang empat kali. Benih yang digunakan berukuran rata-rata $4,9 \mathrm{~cm}$. Padat tebar yang digunakan adalah 50 ekor/akuarium. Ukuran akuarium yang digunakan $50 \mathrm{~cm} \times 85 \mathrm{~cm} \times 25 \mathrm{~cm}$. Pemeliharaan dilakukan selama dua bulan. Pengamatan pertumbuhan dilakukan setiap lima belas hari. Sintasan dihitung pada akhir penelitian.

\section{Eksperimen-3: Pemeliharaan Benih dalam Waring dengan Padat Tebar Berbeda}

Pada eksperimen-3 dilakukan pemeliharaan benih dalam waring yang ditempatkan dalam kolam tanah dengan padat tebar yang berbeda. Padat tebar yang diujikan adalah 10 dan 20 ekor $/ \mathrm{m}^{2}$. Perlakuan diulang sebanyak tiga kali. Ukuran rata-rata benih yang digunakan $4,8 \mathrm{~cm}$. Ukuran waring yang digunakan adalah $3 \mathrm{~m} \times 2 \mathrm{~m} \times 1 \mathrm{~m}$. Selama pemeliharaan, benih diberi pakan berupa cacing tubifex. Pemeliharaan dilakukan selama dua bulan. Parameter yang diamati berupa pertumbuhan dan sintasan.

\section{Eksperimen-4: Pembesaran dalam Waring dengan Jenis Pakan Berbeda}

Pada eksperimen-4 dilakukan pengujian berupa pemeliharaan benih dengan pemberian jenis pakan yang berbeda yaitu: cacing tubifex, cacing tubifex + pakan buatan, dan pakan buatan. Setiap perlakuan diulang sebanyak tiga kali. Ukuran rata-rata benih yang digunakan 8,3 cm. Pakan buatan yang diberikan berbentuk pasta dengan kadar protein $40 \%$ Campuran cacing tubifex + pakan buatan dilakukan dengan perbandingkan bobot 1:1 dalam bentuk pasta. 


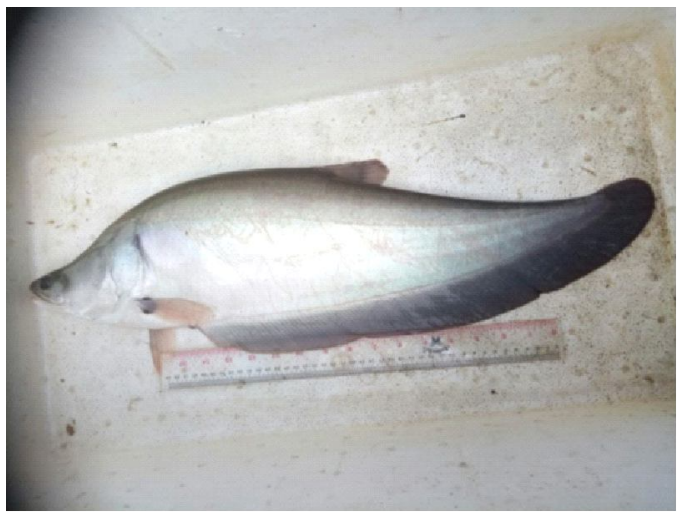

Induk ikan belida (A)

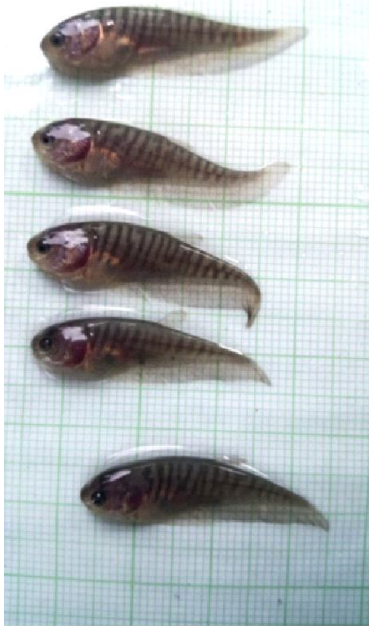

Benih ikan belida (B)

Gambar 1. Induk ikan belida hasil seleksi (A) dan benih ikan belida hasil pemijahan alami di kolam tanah (B).

Figure 1. Selected broodstock (A) and fingerling of featherback produced from natural breeding program in earthen pond (B).

Pemeliharaan dilakukan dalam waring berukuran $2 \mathrm{~m}$ $\times 3 \mathrm{~m} \times 1 \mathrm{~m}$ selama dua bulan. Padat tebar yang digunakan adalah $9 \mathrm{ekor} / \mathrm{m}^{2}$. Pengamatan dilakukan setiap bulan. Parameter yang diamati antara lain: pertumbuhan dan sintasan.

\section{HASIL DAN BAHASAN}

Pemijahan alami yang dilakukan di kolam tanah dengan memasangkan 20 ekor induk betina dan 15 ekor induk jantan secara massal menghasilkan benih ikan belida sebanyak 1.205 ekor dengan ukuran ratarata panjang total $3,4 \mathrm{~cm}$ dan bobot tubuh $0,40 \mathrm{~g}$ (Tabel 1). Hasil ini lebih tinggi dibandingkan dengan yang dilakukan oleh Haniffa et al. (2004) menggunakan induk hasil pemeliharaan selama satu tahun. Dari 50 pasang induk jantan dan betina yang dipijahkan dihasilkan 445 ekor benih dengan ukuran rata-rata 3,4 $\mathrm{cm}$ dan bobot rata-rata 0,45 g. Yanwirsal et al. (2017) mencatat bahwa jumlah telur yang dihasilkan secara alami oleh induk ikan belida adalah berkisar antara 25 hingga 225 butir/induk. Sedangkan Lestari (2010) mendapatkan bahwa jumlah telur induk ikan belida berkisar antara 442-11.972 butir. Larva ikan belida berumur 25-30 hari telah berubah bentuk menjadi benih dengan ukuran rata-rata 2,7 cm (Srivastava et al., 2012). Keadaan ini dapat memberikan informasi bahwa estimasi jumlah induk yang memijah di kolam tanah berkisar antara 2-3 ekor, dan larva yang berhasil dipanen telah berumur lebih dari 30 hari.

Tabel 1. Produksi benih induk ikan belida hasil pemijahan secara alami

Table 1. Production of featherback fingerling from natural breeding

\begin{tabular}{lc}
\hline \multicolumn{1}{c}{ Parameter (Parameters) } & Nilai (Value) \\
\hline Jumlah induk betina (ekor) / Number of female broodstock (ind.) & 20 \\
Jumlah induk jantan (ekor) / Number of male broodstock (ind.) & 15 \\
Bobot induk betina (W eight of female broodstock) (kg) & $1.2-3.3$ \\
Panjang total induk betina (Total length of female broodstock) (cm) & $56-67$ \\
Bobot induk jantan (W eight of male broodstock) (kg) & $0.8-1.6$ \\
Panjang total induk jantan (Total length of male broodstock) (cm) & $51-64$ \\
Jumlah benih (ekor) / Number of fingerling (ind.) & 1.205 \\
Panjang total benih (Total length of fingerling) (cm) & $3.4 \pm 0.08$ \\
Bobot benih (Weight of fingerling) (g) & $0.4 \pm 0.03$ \\
\hline
\end{tabular}




\section{Eksperimen-1}

Benih ikan belida yang dipelihara pada padat tebar 45 dan 90 ekor/90 L menunjukkan pertumbuhan lebih cepat dibandingkan padat tebar 180 ekor/90 L seperti tertera pada Tabel 2 dan Gambar 2. Nilai rata-rata pertumbuhan panjang spesifik benih ikan belida pada padat tebar 45 dan 90 ekor/L adalah 1,3\%hari. Laju pertumbuhan spesifik panjang terendah adalah 1,0\% hari pada padat tebar 180 ekor/90L. Sedangkan ratarata pertumbuhan bobot spesifik harian dengan nilai tertinggi 3,1\% (45 ekor/90 L) dan terendah 2,9\% (90 dan 180 ekor/90 L). Nilai pertumbuhan spesifik ini lebih tinggi dibandingkan dengan nilai yang diamati oleh Nuryadi \& Setijaningsih (2015) pada benih yang dipelihara pada berbagai tingkat intensitas cahaya yaitu 0,38\%0,60\%(panjang) dan 0,57\%1,00\%(bobot).
Sintasan benih ikan belida pada tahapan pembenihan berkisar antara 90,5\%(180 ekor/90 L) dan 96,7\% (90 ekor/90 L). Nilai ini lebih tinggi bila dibandingkan dengan hasil penelitian Nuryadi \& Setijaningsih (2015) yang mendapatkan tingkat sintasan benih pada saat pembenihan berkisar antara $46,67 \% 75,56 \%$ Hal ini menandakan bahwa peningkatan kepadatan memengaruhi laju pertumbuhan namun tidak memberikan pengaruh yang nyata terhadap sintasan benih ikan belida sehingga kepadatan yang disarankan untuk pendederan adalah 90 ekor/90L.

\section{Eksperimen-2}

Nilai rata-rata pada laju pertumbuhan spesifik bobot benih ikan belida yang diberi pakan buatan sebesar 0,9\% hari sedangkan yang diberi cacing tubi-

Tabel 2. Pertumbuhan dan sintasan benih ikan belida yang dipelihara dalam akuarium dengan padat tebar yang berbeda

Table 2. Growth and survival rate of featherback fingerling reared in aquaria with different densities

\begin{tabular}{lccc}
\hline \multirow{2}{*}{ Parameter (Parameters) } & \multicolumn{4}{c}{ Padat tebar (ekor/90 L)/ Density (ind./90 L) } \\
\cline { 2 - 4 } & $\mathbf{4 5}$ & $\mathbf{9 0}$ & $\mathbf{1 8 0}$ \\
\hline Panjang awal (Initial length) (mm) & $34.4 \pm 0.02$ & $33.3 \pm 0.07$ & $34.7 \pm 0.16$ \\
Panjang akhir (Final length) (mm) & $50.4 \pm 0.11$ & $49.0 \pm 0.13$ & $46.4 \pm 0.08$ \\
Bobot awal (Initial weight) (g) & $0.4 \pm 0.00$ & $0.4 \pm 0.01$ & $0.4 \pm 0.09$ \\
Bobot akhir (Final weigth) (g) & $1.0 \pm 0.06$ & $0.9 \pm 0.03$ & $0.9 \pm 0.07$ \\
$\begin{array}{l}\text { Laju pertumbuhan spesifik panjang } \\
\text { Specific growth rate of length (\%) }\end{array}$ & 1.3 & 1.3 & 1.0 \\
Laju pertumbuhan spesifik bobot & 3.1 & & \\
$\begin{array}{l}\text { Specific growth rate of weight (\%) } \\
\text { Sintasan (Survival rate) (\%) }\end{array}$ & $91.3 \pm 4.67$ & $96.7 \pm 1.33$ & $90.5 \pm 5.97$ \\
\hline
\end{tabular}
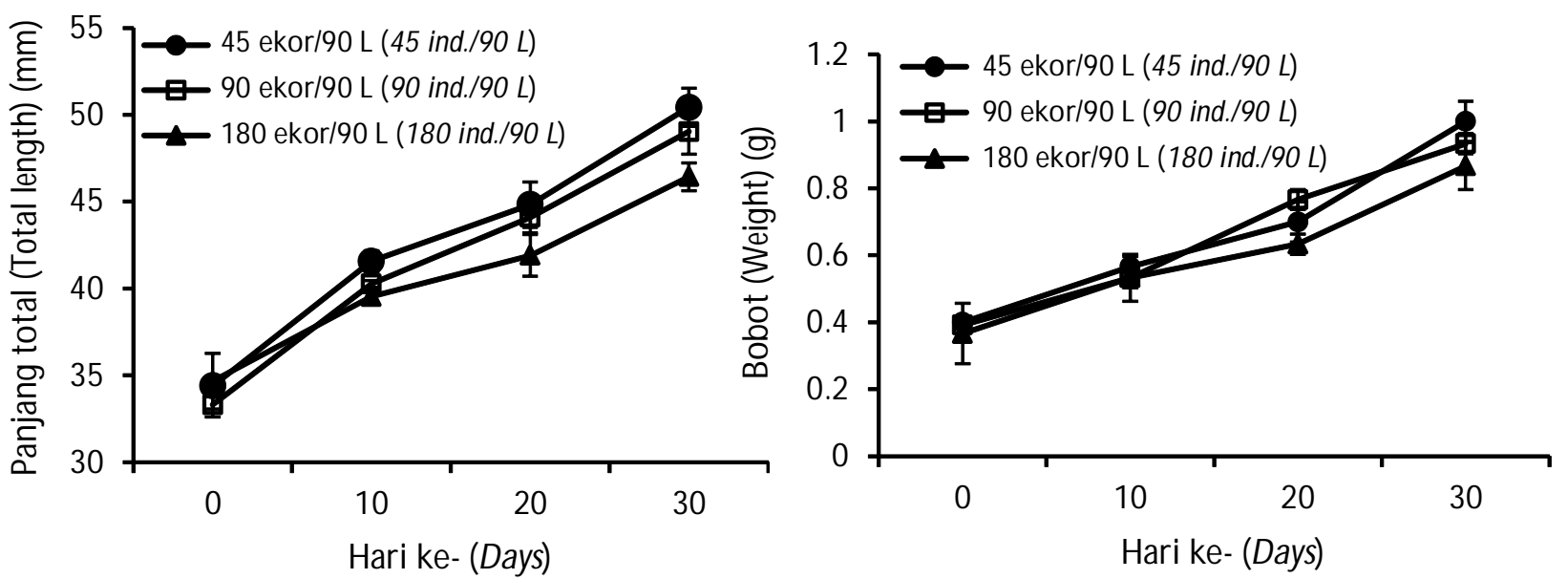

Gambar 2. Pola pertumbuhan benih ikan belida yang dipelihara dalam akuarium dengan padat tebar yang berbeda.

Figure 2. Growth pattern of featherback fingerling reared in aquaria with different densities. 
fex sebesar 2,0\%hari. Adapun laju pertumbuhan spesifik panjang pada benih ikan belida yang diberi pakan buatan adalah $0,3 \%$ hari sedangkan yang diberi cacing tubifex adalah $0,7 \%$ hari (tubifex). Pertambahan bobot dan panjang total benih ikan belida selama pemeliharaan di akuarium tertera pada Tabel 3 dan Gambar 3. Pertumbuhan benih ikan belida yang diberi pakan berupa cacing tubifex lebih cepat dibandingkan pakan buatan. Apabila dibandingkan dengan hasil penelitian Nuryadi \& Setijaningsih (2015), di mana benih ikan belida pada ukuran yang relatif sama diberi pakan berupa larva ikan mas menunjukkan laju pertumbuhan spesifik sebesar 0,57\%1,0\%(bobot) dan $0,38 \% 0,60 \%$ (panjang). Hasil riset terdahulu ini menunjukkan laju pertumbuhannya relatif sama dengan hasil diperoleh pada penelitian yang dilakukan dengan pakan buatan. Pengamatan memperlihatkan bahwa benih ikan belida baru memakan pakan buatan pada hari ketiga. Hal ini membuka peluang untuk mengubah kebiasaan pakan benih ikan belida dari yang semula berupa pakan alami menjadi pakan buatan. Penyesuaian pakan dari pakan hidup ke pakan buatan perlu dilakukan untuk keperluan domestikasi dan agar laju pertumbuhan spesifik benih ikan belida dapat setara dengan hasil pemberian pakan alami.

Sintasan benih ikan belida yang diberi pakan buatan ataupun cacing tubifex cenderung sama (Tabel 3). Nilai sintasan rata-rata berkisar antara 29,0\% (cacing tubifex) dan 29,5\%(pakan buatan). Nuryadi \& Setijaningsih (2015) mendapatkan tingkat sintasan berkisar antara $46,67 \% 75,56 \%$ dengan menggunakan ukuran benih yang lebih besar $5-6 \mathrm{~cm}$.

\section{Eksperimen-3}

Pada pemeliharaan benih di waring dengan padat tebar berbeda menunjukkan bahwa laju pertumbuhan spesifik bobot benih ikan belida berkisar antara 2,4\% hari untuk padat tebar 20 ekor $/ \mathrm{m}^{2}$ hingga 2,6\% hari untuk padat tebar 10 ekor $/ \mathrm{m}^{2}$. Sedangkan laju pertumbuhan spesifik panjang benih berkisar antara 0,9\% hari untuk padat tebar $20 \mathrm{ekor} / \mathrm{m}^{2}$ hingga 1,0\% hari untuk padat tebar $10 \mathrm{ekor} / \mathrm{m}^{2}$ (Tabel 4). Sintasan benih ikan belida adalah 77,3\% pada padat tebar 10 ekor $/ \mathrm{m}^{2}$ dan 87,5\%pada padat tebar 20 ekor $/ \mathrm{m}^{2}$.

\section{Eksperimen-4}

Laju pertumbuhan spesifik bobot benih ikan belida pada saat pembesaran yang tertinggi dihasilkan pada perlakuan pakan cacing tubifex yaitu 1,3\%hari; kemudian diikuti oleh perlakuan pakan campuran cacing tubifex + pakan buatan yaitu 1,0\% hari; dan yang terendah pada perlakuan pakan buatan dengan nilai $0,6 \%$ hari. Laju pertumbuhan spesifik pada karakter panjang relatif sama antar perlakuan yaitu 0,4\% /hari (Tabel 5). Namun pada karakter bobot, laju pertumbuhan spesifik pada perlakuan cacing lebih tinggi dibandingkan perlakuan Iainnya. Pola pertumbuhan ikan belida pada tahap pembesaran menunjukkan pertumbuhan bobot lebih cepat dibandingkan panjang. Lestari (2010) mendapatkan bahwa pola pertumbuhan ikan belida saat dewasa bersifat alometrik positif (+) yang menunjukkan bahwa pertumbuhan bobot lebih cepat dibandingkan panjang. Nilai rata-rata sintasan benih ikan belida saat pembesaran selama dua bulan masa pemeliharaan pada perlakuan pemberian pakan berupa cacing tubifex, pakan buatan, dan pakan campuran secara berturutturut adalah 88,7\% 91,8\% dan 93,1\%(Tabel 5).

Pada penelitian ini, stimulasi lingkungan yang cocok dengan kebutuhan fisiologi reproduksi induk, diduga menjadi pemacu berkembangnya gonad sehingga induk ikan belida mampu memijah secara

Tabel 3. Pertumbuhan dan sintasan benih ikan belida yang dipelihara dalam akuarium dengan jenis pakan berbeda

Table 3. Growth and survival rate of featherback fingerling reared in aquaria with different feeds

\begin{tabular}{lcc}
\hline \multirow{2}{*}{ Parameter (Parameters) } & \multicolumn{2}{c}{ Jenis pakan (Feed) } \\
\cline { 2 - 3 } & Pakan buatan (Artificial feed) & Cacing tubifex (Tubifex) \\
\hline Bobot awal (Initial weight) $(\mathrm{g})$ & $0.8 \pm 0.08$ & $0.9 \pm 0.00$ \\
Bobot akhir (Final weigth) $(\mathrm{g})$ & $1.4 \pm 0.11$ & $3.0 \pm 0.10$ \\
Panjang total awal (Initial total length) (cm) & $4.9 \pm 0.17$ & $4.9 \pm 0.04$ \\
Panjang total akhir (Final total length) (cm) & $6.0 \pm 0.06$ & $7.3 \pm 0.03$ \\
Laju pertumbuhan spesifik bobot & 0.9 & 2.0 \\
Specific growth rate of weight (\%) & 0.3 & 0.7 \\
Laju pertumbuhan spesifik panjang & $29.5 \pm 3.30$ & $29.0 \pm 3.42$ \\
Specific growth rate of length (\%) & & \\
Sintasan (Survival rate) (\%) & &
\end{tabular}



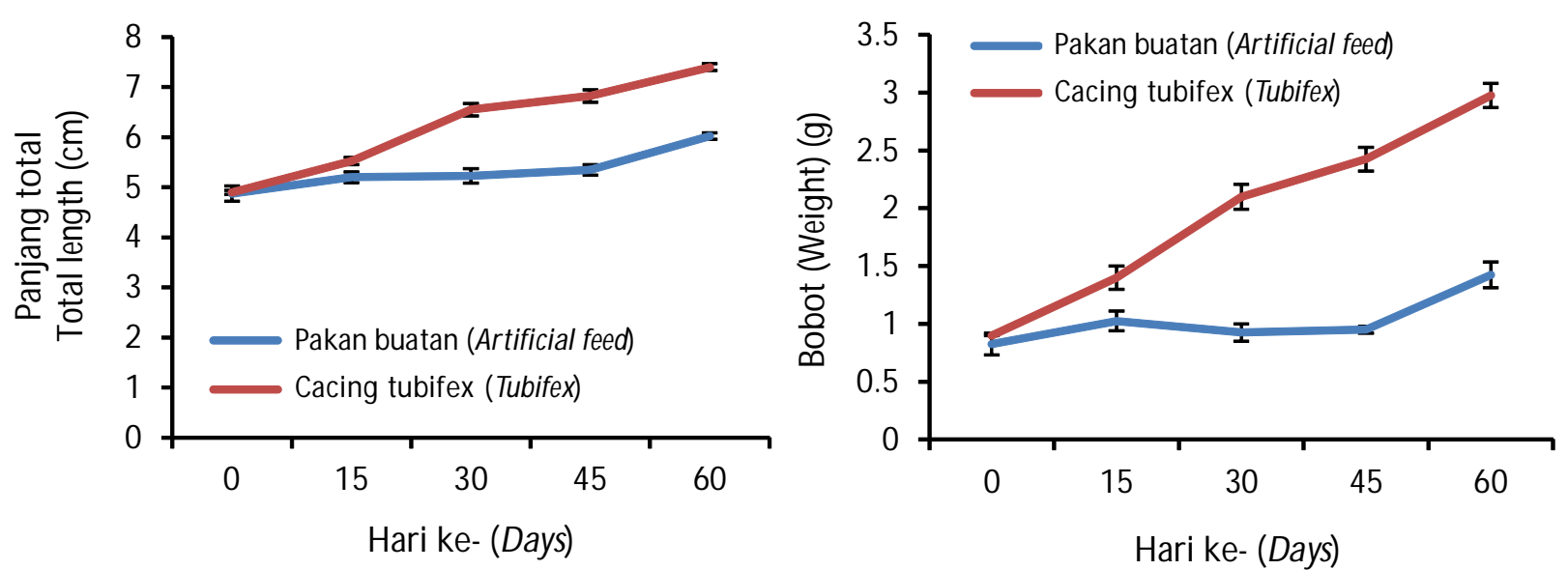

Gambar 3. Pola pertumbuhan benih ikan belida yang dipelihara dalam akuarium dengan jenis pakan berbeda.

Figure 3. Growth pattern of featherback fingerling reared ini aquaria with different feeds. (red lines $=$ tubifex worm; blue lines $=$ artificial feed)

Tabel 4. Pertumbuhan dan sintasan benih ikan belida yang dipelihara dalam waring dengan padat tebar berbeda

Table 4. Growth and survival rate of featherback fingerling reared in net cage with different densities

\begin{tabular}{lcc}
\hline \multirow{2}{*}{ Parameter (Parameters) } & \multicolumn{2}{c}{ Padat tebar (ekor $/ \mathbf{m}^{\mathbf{2}}$ )/ Density (ind./ $\mathbf{~}^{\mathbf{2}}$ ) } \\
\cline { 2 - 3 } & $\mathbf{1 0}$ & $\mathbf{2 0}$ \\
\hline Panjang awal (Initial length) (cm) & $4.8 \pm 0.03$ & $4.8 \pm 0.09$ \\
Panjang akhir (Final length) (cm) & $9.3 \pm 0.34$ & $8.9 \pm 0.38$ \\
Bobot awal (Initial weight) (g) & $0.9 \pm 0.03$ & $0.9 \pm 0.06$ \\
Bobot akhir (Final weigth) (g) & $5.2 \pm 0.15$ & $4.4 \pm 0.54$ \\
Laju pertumbuhan spesifik panjang (Specific growth rate of length) (\%) & 1.0 & 0.9 \\
Laju pertumbuhan spesifik bobot (Specific growth rate of weight) (\%) & 2.6 & 2.4 \\
Sintasan (Survival rate) (\%) & 77.3 & 87.5 \\
\hline
\end{tabular}

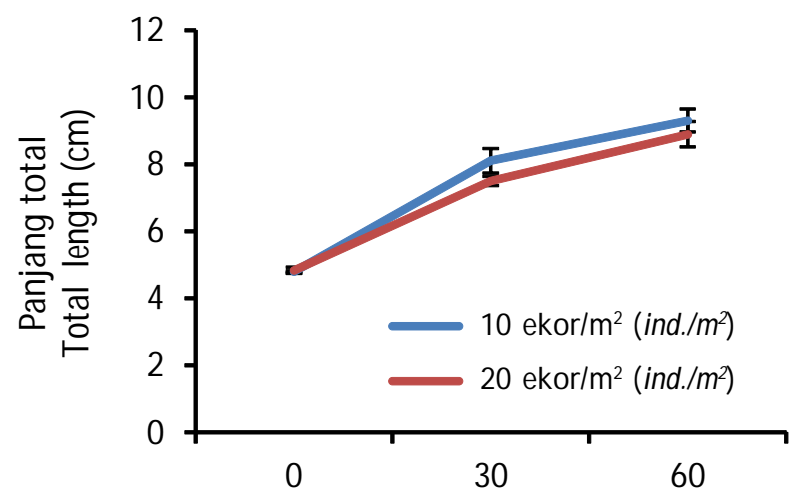

Hari ke- (Days)

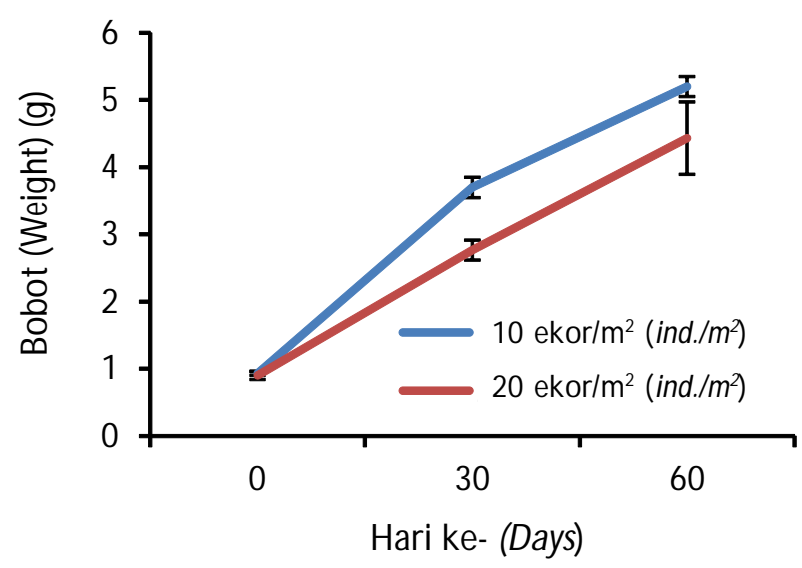

Gambar 4. Pola pertumbuhan benih ikan belida yang dipelihara dalam waring dengan padat tebar berbeda.

Figure 4. Growth pattern of featherback fingerling reared in net cage with different densities (blue line $=10$ ind. $/ \mathrm{m}^{2}$; red line $=20$ ind. $\left./ \mathrm{m}^{2}\right)$. 
Tabel 5. Pertumbuhan dan sintasan ikan belida yang dipelihara dalam waring dengan jenis pakan berbeda pada tahap pembesaran

Table 5. Growth dan survival rate of featherback reared in net cage with different feeds in grow out phase

\begin{tabular}{lccc}
\hline \multirow{2}{*}{ Parameter (Parameters) } & \multicolumn{3}{c}{ Jenis pakan (Feed) } \\
\cline { 2 - 5 } & $\begin{array}{c}\text { Cacing tubifex } \\
\text { Tubifex }\end{array}$ & $\begin{array}{c}\text { Pakan buatan } \\
\text { Artificial feed }\end{array}$ & $\begin{array}{c}\text { Cacing tubifex + pakan buatan } \\
\text { Tubifex + artificial feed }\end{array}$ \\
\hline Bobot awal (Initial weight) $(\mathrm{g})$ & $3.9 \pm 0.03$ & $4.0 \pm 0.09$ & $3.9 \pm 0.05$ \\
Bobot akhir (Final weigth) (g) & $6.1 \pm 0.29$ & $4.9 \pm 0.61$ & $5.6 \pm 0.75$ \\
Panjang total awal (Initial total length) (cm) & $8.6 \pm 1.16$ & $8.1 \pm 1.04$ & $8.3 \pm 0.92$ \\
Panjang total akhir (Final total length) (cm) & $9.8 \pm 1.17$ & $9.1 \pm 4.71$ & $9.6 \pm 4.27$ \\
Laju pertumbuhan spesifik bobot & 1.3 & 0.6 & 1.0 \\
Specific growth rate of weight (\%) & & & 0.4 \\
Laju pertumbuhan spesifik panjang & 0.4 & 0.4 & $93.1 \pm 1.66$ \\
$\begin{array}{l}\text { Specific growth rate of length (\%) } \\
\text { Sintasan (Survival rate) (\%) }\end{array}$ & $88.7 \pm 2.88$ & $91.8 \pm 2.27$ & \\
\hline
\end{tabular}

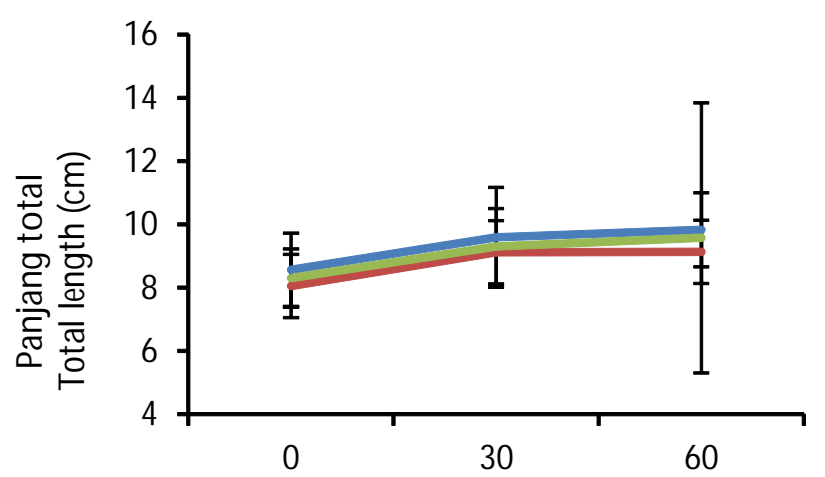

Cacing tubifex (Tubifex)

Pakan buatan (Artificial feed)

Cacing tubifex+ pakan buatan (Tubifex+ artificial feed)

Hari ke- (Days)

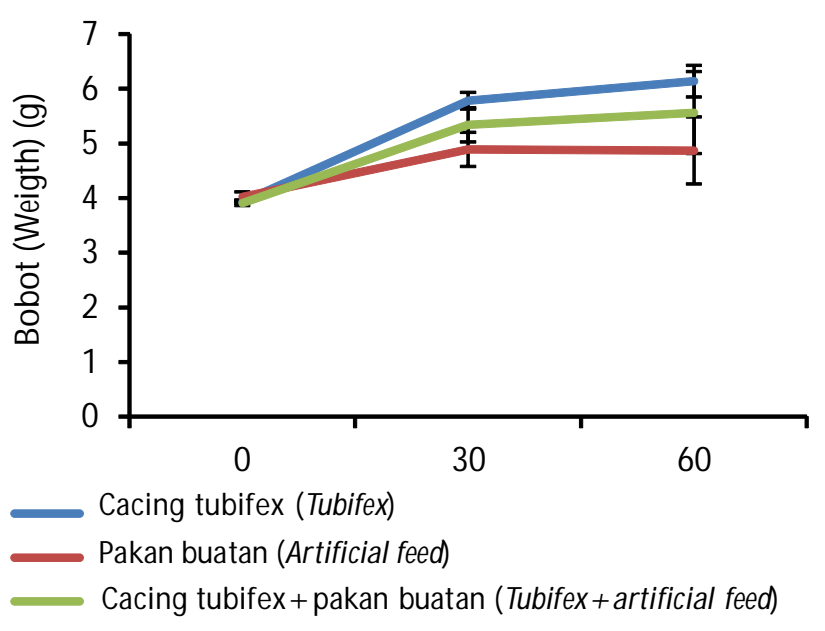

Hari ke- (Days)

Gambar 5. Pola pertumbuhan ikan belida yang diberi jenis pakan berbeda pada tahap pembesaran.

Figure 5. Growth pattern of featherback fed with different feeds in grow out phase. (Blueline= tubifex worm; Red line $=$ artificial feed; Green line $=$ tubifex worm + artificial feed).

alami. Menurut Adjie et al. (1999), ikan belida dapat memijah sepanjang tahun dengan puncak musim pemijahan terjadi pada saat musim kemarau.

Selama dipelihara dalam akuarium, benih diberi pakan berupa cacing tubifex. Setelah satu bulan pemeliharaan, benih ikan belida yang berumur dua bulan dapat dipindahkan ke dalam waring yang ditempatkan dalam kolam tanah dan mulai diberi pakan buatan berbentuk pasta. Kolam yang kaya akan pakan alami dapat membantu mempercepat pertumbuhan benih ikan belida.
Berdasarkan kriteria level domestikasi pada Tabel 6 (Teletchea \& Fontaine, 2014), teknologi budidaya ikan belida yang dihasilkan dari penelitian ini dapat dikategorikan masuk ke dalam level-2, yaitu induk masih diperoleh dari alam dan diberi pakan berupa ikan kecil, pemijahan sudah dapat dilakukan dalam lingkungan terkontrol di luar habitat alaminya, benih dapat memanfaatkan pakan buatan untuk menunjang kelangsungan hidup dan pertumbuhannya. Diharapkan induk generasi mendatang pakannya tidak lagi bergantung pada pakan hidup sehingga level 
Tabel 6. Level domestikasi ikan menurut Teletchea \& Fontaine (2014)

Table 6. Domestication level for fish according to Teletchea \& Fontaine (2014)

\begin{tabular}{|c|c|c|}
\hline $\begin{array}{l}\text { Level domestikasi } \\
\text { Domestication level }\end{array}$ & Deskripsi (Description) & Contoh (Example) \\
\hline 0 & Ikan tangkapan (Capture fisheries) & \\
\hline 1 & $\begin{array}{l}\text { Ujicoba untuk aklimatisasi dalam lingkungan budidaya } \\
\text { First trials of acclimatization to the culture environment }\end{array}$ & Blicca bjoerkna \\
\hline 2 & $\begin{array}{l}\text { Sebagian siklus hidup dapat dilakukan dalam wadah budidaya, tapi } \\
\text { masih ada beberapa kendala (contoh: reproduksi, pemeliharaan } \\
\text { larva, dan lain-lain) } \\
\text { Part of the life cycle is completed in captivity, but several important } \\
\text { bottlenecks still exist in others (e.g. reproduction,larval rearing) }\end{array}$ & $\begin{array}{l}\text { Misgurnus } \\
\text { anguillicaudatus, } \\
\text { Seriola quinqueradiata, } \\
\text { Thunnus thynnus, } \\
\text { Anguilla Anguilla }\end{array}$ \\
\hline 3 & $\begin{array}{l}\text { Seluruh siklus hidup dalam wadah budidaya, namun menggunakan } \\
\text { input dari alam (contoh: pakan hidup) } \\
\text { The entire life cycle is closed in captivity, but with wild inputs }\end{array}$ & $\begin{array}{l}\text { Thunnus orientalis, } \\
\text { Solea senegalensis, } \\
\text { Rutilus rutilus }\end{array}$ \\
\hline 4 & $\begin{array}{l}\text { Seluruh siklus hidup dalam wadah budidaya tanpa input dari alam, } \\
\text { belum ada program selective breeding } \\
\text { The entire life cycle is closed in captivity without wild inputs, but no sel ective } \\
\text { breeding programme is used }\end{array}$ & $\begin{array}{l}\text { Catla catla, } \\
\text { Channa argus, } \\
\text { Cirrhinus mrigala, } \\
\text { Sander lucioperca, } \\
\text { Perca fluviatilis }\end{array}$ \\
\hline 5 & $\begin{array}{l}\text { Program selective breeding digunakan untuk tujuan spesifik } \\
\text { (pertumbuhan, kualitas daging, dan lain-lain) } \\
\text { Selective breeding programme is used focusing on specific goals (growth } \\
\text { rate, fillet yield, flesh quality) }\end{array}$ & $\begin{array}{l}\text { Cyprinus carpio, } \\
\text { Oncorhynchus mykiss, } \\
\text { Salmo salar, } \\
\text { Dicentrarchus labrax }\end{array}$ \\
\hline
\end{tabular}

domestikasinya dapat meningkat, dan seluruh siklus hidupnya sudah dapat dilakukan dalam wadah budidaya secara terkontrol. Menurut Bilio (2007), spesies ikan dapat disebut terdomestikasi apabila dapat bereproduksi paling sedikit tiga siklus (generasi) dalam wadah budidaya.

\section{KESIMPULAN}

Ikan belida hasil tangkapan alam dapat dipijahkan secara alami dalam kolam budidaya. Benih berukuran 3-4 cm dapat dipelihara dalam akuarium dan diberi pakan berupa cacing tubifex. Padat tebar yang menghasilkan laju pertumbuhan bobot tertinggi sebesar 1,3\% /hari adalah 45 ekor/90 L. Pakan benih berukuran rata-rata $4,9 \mathrm{~cm}$ yang menghasilkan laju pertumbuhan tertinggi sebesar 2,0\% hari adalah cacing tubifex. Padat tebar dalam waring yang menghasilkan pertumbuhan bobot tertinggi sebesar 2,6\% hari adalah $10 \mathrm{ekor} / \mathrm{m}^{2}$. Pakan pada benih ukuran $8-9 \mathrm{~cm}$ yang memberikan pertumbuhan bobot tertinggi sebesar 1,3\% hari adalah cacing tubifex.

\section{UCAPAN TERIMA KASIH}

Penelitian ini dibiayai oleh Pusat Riset Perikanan pada Tahun Anggaran 2018. Ucapan terima kasih disampaikan kepada Kepala Pusat Riset Perikanan dan
Dr. Endhay Kusnendar yang telah memberikan dukungan selama penelitian ini berlangsung.

\section{DAFTAR ACUAN}

Adjie, S., Husnah, \& Gaffar, A.K. (1999). Studi biologi ikan belida Notopterus chitala di daerah aliran Sungai Batanghari Provinsi Jambi. Jurnal Penelitian Perikanan Indonesia, 5(1), 38-43.

Bilio, M. (2007).Controlled reproduction and domestication in aquaculture - the current state of the art, Part I. Aquaculture Europe, 32, 5-14.

Driscoll, C.A., Macdonald, D.W., \& O'Brien, S.J. (2009). From wild animals to domestic pets, an evolutionary view of domestication. Proceedings of the National Academy of Sciences of the United States of America, 106, 9971-9978.

Gustomi, A., Sulistiono, \& Yonvitner. (2016). Biologi reproduksi ikan belida (Notopterus notopterus Pallas, 1769) di Kolong-Bendungan Simpur, Pulau Bangka. Jurnal IImu Pertanian Indonesia (JIPI), 21(1), 56-62.

Haniffa, M.A., Arockia-Raj A.J., Nagarajan, M., Perumalsamy, P., Seetharaman, S., \& Singh, S.P. (2004). Natural breeding in captivity: A possibility for conservation of threatened freshwater featherback Notopterus notopterus. AquacultureAsia, 9(1), 36-38. 
Hossain, Q.Z., Hossain, M.A., \& Parween, S. (2006). Breeding biology, captive breeding and fry nursing of humped featherback (Notopterus chitala, Hamilton-Buchanan, 1822). Ecoprint, 13, 41-47.

Kohinoor, A.H.M., Jahan, D.A., Khan, M.M., Islam, M.S., \& Hussain.M.G. (2012). Reproductive biology of feather back, chital (Notopterus chitala, Ham.) cultured in a pond of Bangladesh. Int. J. Agril. Res. Innov. \& Tech., 2(1), 26-31.

Kristanto, A.H., Nuryadi, Yosmaniar, \& Sutrisno. (2008). Perkembangan variasi telur dan sperma ikan belida yang dipelihara di kolam. Jurnal Riset Akuakultur, 3(1), 73-82.

Lestari, M. (2010). Biologi reproduksi ikan belida (Chitala lopis) di daerah aliran Sungai Kampar, Riau. Skripsi. Fakultas Perikanan dan IImu Kelautan, Institut Pertanian Bogor. Bogor, $60 \mathrm{hlm}$.

Nuryadi, \& Setijaningsih, L. (2015). Perbedaan intensitas cahaya pada pembenihan ikan belida (Notopterus chitala). Prosiding Forum Inovasi Teknologi Akuakultur . Jakarta, hlm. 1009-1014.

Sarkar, U.K., Deepak, P.K., \& Lakra, W.S. (2009). Stock identification of endangered clown knife fish Chitala chitala (Hamilton-Buchanan, 1822) from indian rivers inferred by morphological attributes. Electronic Journal of Ichthyology, 2, 59-75.
Sodsuk, P.K. \& Sodsuk, S. (2000). Genetic diversity of featherback fish in Thailand. Kasetsart J. (Nat. Sci.), 34, 227-239.

Srivastava, S.M., Gopalakrishnan, A., Singh, S.P., \& Pandey, A.K. (2012). Embryonic and larval development of threatened bronze featherback Notopterus notopterus (Pallas).J. Exp. Zool. India , 15(2), 425-430.

Srivastava, S.M., Srivastava, P.P., Dayal, R., Pandey, A.K., \& Singh, S.P. (2010). Induced spawning of caprive stock of threatened bronze featherback, Notopterus notopterus, for stock improvement and conservation. J. Appl. Biosci., 36(2), 144-147.

Teletchea, F. \& Fontaine, P. (2014). Levels of domestication in fish: implications for the sustainable future of aquaculture. Fish and Fisheries, 15, 181-195.

Wibowo, A. \& Marson. (2012). Fenomena plastisitas fenotipik ikan belida (Chitalalopis) di Sungai Kampar, Riau. Bawal, 4(3), 195-204.

Yanwirsal, H., Bartsch, P., \& Kirschbaum. (2017). Reproduction and development of the Asian bronze featherback Notopterus notopterus (Pallas, 1769) (Osteoglossiformes, Notopteridae) in captivity. Zoosyst.Evol., 93(2), 299-324. 